\title{
Study on Personnel Training Mode of Financial Management
}

\author{
Yu Zhang \\ School of Economics and Management, Qingdao University of Science and Technology, Qingdao \\ 266061, China. \\ qdzhangyu@126.com
}

\begin{abstract}
Training mode research of financial management is increasingly important. The training target of financial management major, its problems and countermeasures are studied in order to rationalize the relationship between the target of Talent training and curriculum. The paper emphasizes the importance of case teaching method in the applied talents education, and the college should improve the practice teaching level of teachers, in order to meet the social needs of the financial management professional personnel.
\end{abstract}

Keywords: Financial management; case method; personnel training mode.

\section{Introduction}

The development of the market economy needs the institutions to cultivate financial management of strong ability to adapt the practice. The main professional purpose of the financial management is behind the demand of a market economy. And the biggest problem is the teaching theory far away from practice. When the financial managerial talent can't match with the social economic, political, and cultural development, we must reform the current training model to build innovative training model.

At present, there are many domestic academic literature of financial management profession. Liu Jun (1993) for the first time defined personnel training mode that is a teaching mode for achieving certain goals of education under certain conditions. And some authors thought the training mode is a kind of operation mechanism.

\section{Financial Management Major Talents Targeting}

In order to optimize the knowledge structure and ensure the integrity and systematic knowledge structure, the teachers should achieve positive interaction among professional financial management and other professional. Financial management major students should learn the basis of economics, management, accounting, tax law, economic law and other professional courses when learning the basis of a comprehensive and systematic theories and methods of financial management. In addition, students should select such courses as project evaluation, etc. designed to broaden students' horizons, broaden their knowledge and reinforce the professional basis of professional electives [1]. Financial management students should have good political and humane quality; have a solid financial management expertise, have a strong capacity for innovation and practical ability, have the necessary self-learning ability and scientific research ability and have a strong sense of the market economy. Of course, the students should also have social adaptation and professional conversion ability and have strong organizational skills [2]. Financial management trains the students who have solid financial management skills of professional knowledge and skills, familiar with the basic knowledge of financial discipline, economics and laws [3].

\section{Financial Management Personnel Training Problems}

\subsection{Talents Concept Obsolete.}

From the current financial management training mode, the curriculum of most universities is mainly theoretical courses, and seldom practical courses. Colleges focus on theoretical professional knowledge, but ignore capacity-building. In order to pursuit to cultivate the mastering level of the 
investment, financing and capital operation, daily analysis, decision-making and advisory capacities the courses lass of the cultivating of the basic financial management personnel. The major should give the most students who can do the financial job in the business enterprises and securities companies and institutions and government departments.

\subsection{Profession Lack of Features.}

College financial management major curriculum lacks of features. The majors of financial management, finance and accounting curriculum system are the same, especially, the curriculum is basically the same in the major of accounting and financial management, both include basic accounting, intermediate accounting, advanced accounting and financial management basic, intermediate financial management, advanced financial management. So it is difficult to find the financial management characteristics, and finally the major students are the general accounting generalists. So the paper advises the college should set the major with the chemistry and physical and so on, for example, chemical accounting and so on (Table 1).

Table 1 The comparison among the three majors

\begin{tabular}{|c|c|c|c|}
\hline Courses & Financial Mnagement & Accounting & Finance \\
\hline Microeconomics & $\sqrt{ }$ & $\sqrt{ }$ & $\sqrt{ }$ \\
\hline Macroeconomics & $\sqrt{ }$ & $\sqrt{ }$ & $\sqrt{ }$ \\
\hline Statistics Base & $\sqrt{ }$ & $\sqrt{ }$ & $\sqrt{ }$ \\
\hline Finance Base & $\sqrt{ }$ & $\sqrt{ }$ & $\sqrt{ }$ \\
\hline Financial Management & $\sqrt{ }$ & $\sqrt{ }$ & $\sqrt{ }$ \\
\hline Basic Accounting & $\sqrt{ }$ & $\sqrt{ }$ & $\sqrt{ }$ \\
\hline Intermediate Financial Accounting & $\sqrt{ }$ & $\sqrt{ }$ & $\sqrt{ }$ \\
\hline Tax laws & $\sqrt{ }$ & $\sqrt{ }$ & $\sqrt{ }$ \\
\hline Economic Law & $\sqrt{ }$ & $\sqrt{ }$ & $\sqrt{ }$ \\
\hline Management Accounting & $\sqrt{ }$ & $\sqrt{ }$ & $\sqrt{ }$ \\
\hline Financial Analysis & $\sqrt{ }$ & $\sqrt{ }$ & $\sqrt{ }$ \\
\hline Cost Accounting & $\sqrt{ }$ & $\sqrt{ }$ & $\sqrt{ }$ \\
\hline Investments & $\sqrt{ }$ & $\sqrt{ }$ & $\sqrt{ }$ \\
\hline Risk Management & $\sqrt{ }$ & $\sqrt{ }$ & $\sqrt{ }$ \\
\hline Intermediate Financial Management & $\sqrt{ }$ & $\sqrt{ }$ & $\sqrt{ }$ \\
\hline
\end{tabular}

\subsection{Tax Planning Is Not Obvious in The Courses.}

The financial management course system focus on accounting and financial management, and tax laws and tax planning are not obvious in the courses. Taxation is very important for the enterprise financial management, the students should study the tax avoidance for investment, financing, operation process, profit distribution plan, helping enterprises to reduce the tax burden and achieve the goal of maximizing after-tax profits. Therefore, the curriculum should further increase tax planning lesson hours, increase curriculum practice and encourage students to do the accounting and tax planning practices.

\subsection{Teachers' Lack of Social Practice.}

Most financial management teachers are less contact with business practice. The teaching process is mainly from book to book and emphasizes the theoretical contents of lectures and text exercises. In the training process for young teachers, although the young teachers also accepted the systematic theory knowledge study and training, and some may also be involved in some of the disciplines of research projects engaged in a lot of research work, but most have not undertaken specific financial work in the practice. 


\subsection{Students Have Not Enough Practice.}

At present, financial management students have no enough practice. Moreover, the school financial management students in the practice mainly visit the enterprises, or go flat or books for simple operation, and it is difficult to see real financial management business process such as the decision-making processes. A serious shortage of school practice teaching hours needs changed, and encourages students to do the real accounting job.

\section{Countermeasure of the Financial Management Training}

\subsection{Enhancing the Practical Skills of Teachers.}

Practice social skills of financial management teachers are the key to the implementation of the teaching method reform. To this end, the college can take a planned and phased delivery of teachers to business practice, and the teachers can understand the real situation of the financial operations. And the teachers can solve financial problems in the practice and find the financial cases. This is helpful to the class teaching, and the teachers can improve teaching effectiveness, enrich the content of classroom teaching and enhance students' professional practice [4]. Colleges can also establish a stable base for scientific research and experiment, to carry out the financial management research, business exchanges, technical advice and services in order to support the promotion of teachers' professional quality [5].

\subsection{Reforming Teaching Methods.}

The purpose of the teaching reform is to broaden the way of students learning, develop students' ability to gather ability and acquire new knowledge, analyze and solve problems. In today's information age, students acquire knowledge faster far beyond the imagination of teachers. If the teachers still insist on the authority in the classroom, it will directly affect the students' atmosphere in the class. So the teachers should give more chance to students in order to let them express themselves.

\subsection{Case Lack Real Business Environment Background.}

In the financial management teaching, case teaching method is still in its infancy, and the most cases are from foreign practices and are very simple, not matching the Chinese economic systems and management system. This gives the implementation disadvantages of the financial management case teaching.

So the selection and preparation of the financial management cases is an important measure. First, select the cases of meeting the requirements of the teaching purposes. When describing the background of the events and the political and economic environment, the teachers should tell the attention problems for them to solve them. Secondly, case should have the feature of practices, and can give thinking to students. Generally speaking, good cases can reflect the real economic fact and can include the theoretical knowledge.

\subsection{Strengthen Executive Power of Teaching Evaluation.}

Improving the teaching quality assessment helps to optimize financial management curriculum system, to ensure that in the fierce competition form their own characteristics, and give contributions to society. Quality Evaluation of Universities can not just float in the form. First, from the teachers aspect, referring to today's teaching mode teachers give professional financial management evaluation to adapt to the needs of economic development this perspective, and develop teaching strengths and improve weaknesses. At the same time, teachers also allow students to take part in the classroom teaching evaluation, and students give scores based on their own learning feelings and knowledge obtain level. So the evaluation can develop the teaching mode reform. 


\section{Summary}

All in all, in order to innovative training model of financial management, it is necessary to be based on the business needs and adjust the mode according to the school training actual situation. In order to truly improve students' financial management capacity and meet the needs of enterprise management, the colleges should set school-enterprise double teachers to cultivate students. Through close cooperation processes, it can facilitate information exchange between the two sides to enhance the quality of personnel training. It should be noted that colleges can not be over-socialization and not be market-oriented. College should be responsible for students, not fully in accordance with market demand. Colleges are responsible to deal with and guide teachers to adhere to the teaching spirit and teaching mission of the university.

\section{Acknowledgements}

The paper is one of the research results of Teaching Reform Project Qingdao University of Science and Technology: Colleges compound personnel training model innovation of financial management major.

\section{References}

[1]. Xie Zhengting, Gu Ying. Financial Management of Case Method. Economics.(2009) No.9.

[2]. Xia Jinhai, Research And Application of The Financial Management Case Method. China Township Enterprises Accounting (2008) No.3.

[3]. Zhang Yuying, Financial Management Case Method Research Universities Application [J], accounting communication. Academic Edition (2007) No.4.

[4]. Jin Ying. Discussion. on the financial management of the Teaching in Shijiazhuang College. (2011) No.8.

[5]. Yanjun Ming, Yang Zheng. Compound Talents of Financial Management Research and Practice . Accounting communications, (2011) No.12. 